\title{
Government Official Political Neutrality in Digital Era: Challenge for Administrative Ethics?
}

\author{
Rino A. Nugroho', Dinda Pramitha Shaila Putri², Teguh Budi Santoso ${ }^{3}$, \\ Daffa Rifqi Utomo ${ }^{4}$, Kristina Setyowati ${ }^{5}$ \\ ${ }^{1}$ Departement Of Public Administration, Faculty of Social and Political Sciences, Universitas Sebelas Maret \\ (email: rino.nugroho@staff.uns.ac.id), ${ }^{2}$ Departement Of Public Administration, Faculty of Social and Political \\ Sciences, Universitas Sebelas Maret (email: dindapramithasp@student.uns.ac.id), ${ }^{3}$ Departement Of Public \\ Administration, Faculty of Social and Political Sciences, Universitas Sebelas Maret \\ (email: teguhbs47@student.uns.ac.id), ${ }^{4}$ Departement Of Public Administration, Faculty of Social and Political \\ Sciences, Universitas Sebelas Maret (email: daffarifqiu9@gmail.com), ${ }^{5}$ Departement Of Public Administration, \\ Faculty of Social and Political Sciences, Universitas Sebelas Maret (email: kristina@staff.uns.ac.id)
}

\begin{abstract}
Political neutrality in bureaucracy is facing new challenges in the digital era. Due to its easiness in expressing someone's political views, social media has been chosen by people to be actively involved in politics, including government officials. Public administration scholars believe that to maintain its professionalism, government officials should ethically take a clear distance from practical politics. In order to maintain such professionalism in offline world is easier than in online one. Even though online political activity of government official is apparent, very limited studies had conducted in the area. This study aim is to portray the online political activity of government official by using Indonesian 2019 election as the case study. A datamining from social media is used to collecting the data. Content analysis by using both quantitative and qualitative approach is used for analysing the data. Data is first captured using datamining and then quantitatively displayed using descriptive statistics. Qualitative analysis is conducted for gaining the identity of government officials in certain social media accounts. The result indicates that some government officials were unable to maintain its political neutrality. Further discussion on how political neutrality might challenge administrative ethics is discussed in the full paper.
\end{abstract}

\section{Keywords:}

political neutrality; government official; administrative ethics; social network analysis; hoax

\section{Introduction}

Neutrality of the State Civil Apparatus (SCA) or commonly known as bureaucratic neutrality is one of the important principles that must be used as a guideline by each SCA in carrying out public services, government tasks, and development tasks. The concept of bureaucratic neutrality according to Weber (1978) and Wilson (1941) is very closely related to the political and administrative dichotomy within the bureaucracy. This is useful to 
ensure the competence and immunity of every bureaucratic member of opportunistic ideas introduced by political leadership that is unstable and sometimes also uncertain.

In Indonesia itself, the issue of neutrality of the SCA has been regulated in Law number 5 of 2014 concerning State Civil Apparatus in article 2 F in which neutrality is interpreted that a State Civil Apparatus does not take s side from any form of influence and does not favor the interests of anyone. SCA neutrality becomes very important in Indonesia because a state civil apparatus is a party that directly touches and affects people's lives, which when an SCA is not neutral, it is feared to cause political alignments, injustice in policy making, and implementation of development which will ultimately cause harm to the wider community. Because of its urgency, the bureaucratic neutrality or SCA has also become a fundamental part of the bureaucratic reform agenda that is being implemented by the Indonesian government (Tamma, 2018).

Even though it has been regulated in legislation and made a fundamental part of the bureaucratic reform agenda, several SCAs have also been found to be not neutral and in favor of an interest, especially during the executive and legislative election periods both at national and local levels. This non-neutrality is manifested in a number of actions such as involvement in campaign activities, using state facilities related to job duties, making decisions in favor of its constituents, and holding activities that lead to partiality of one of the candidates in general elections (ELECTION), etc. (Badan Kepegawaian Negara, 2019)

In the current digital era, various acts of non-neutrality are also influenced by the presence of the Internet and social media. Non-neutrality of SCA tends to be demonstrated through social media and digital means rather than conventional media such as influencing others through chatting or using symbols supporting one political candidate. The data from the State Personnel Agency (BKN) shows that as of January 2018 to March 2019, there had been approximately 990 cases of violation of SCA neutrality, mostly carried out through social media, ranging from disseminating images, providing support, commenting, to uploading photos to state partiality against certain candidates in the election (Badan Kepegawaian Negara, 2019).

The shift of the communication and media spectrum to conduct non-neutral behaviors certainly becomes a challenge in realizing the SCA ethical values as regulated in the Law. This is supported by a fake identity factor where in social media, it is possible for a 
person to have more than one identity used to communicate with others to increase one's opportunity, especially SCA, to take neutral actions and violate ethical values.

The government has been trying to anticipate violations of neutrality committed by SCA in social media since 2018 through the Ministry of Empowerment of State Apparatus and Bureaucratic Reform (Kemenpan RB) issuing rules in the form of circular number 137 of 2018 concerning the distribution of Information through Social Media for State Civil Apparatuses. In the circular, it emphasized several things for the SCA in disseminating information through social media such as (1) upholding the Pancasila ideology, being loyal, and keeping the 1945 Constitution of the Republic of Indonesia and the legitimate government, serving the state and people of Indonesia, and performing their duties professionally and impartially, (2) maintaining and upholding high ethical standards, holding SCA basic values and reputation and integrity, (3) maintaining confidentiality regarding state policies, providing information correctly and not misleading to other parties who need information related to official interests, (4) not misusing state internal information to obtain or seek benefits for themselves or for others, (5) using social media wisely directed to strengthen the unity and integrity of the Republic of Indonesia (NKRI), (6) ensuring that the information disseminated is clear from its source, can be accounted for, and does not contain elements of deception, (7) not making and distributing false news (hoaxes), slander, provocation, radicalism, terrorism, and pornography through social media or other media, (8) not producing and distributing information that has a content that causes hatred or hostility of certain individuals and/or groups based on ethnicity, religion, race and intergroup (SARA), decency violation, gambling, insults and/or defamation, extortion and/or threats.

The government has been trying various methods to make SCA remain neutral and professional, but in reality, there are still many SCAs who do not have neutral attitudes, especially in the digital world. This article will discuss further the neutrality of SCA in the digital age by providing a conceptual understanding and examples through a case study and giving the right way to keep SCA neutral in this era based on literature review. 


\subsection{Bureaucracy Neutrality}

State Civil Apparatus is a concept that cannot be separated from the concept of bureaucracy, especially bureaucratic neutrality which is the main study in this article. Discourse related to neutrality in the bureaucracy itself always starts with a discussion about the development of the paradigm of state administration from the dichotomy of "politics" and "administration". Understanding that politics and administration are separate matters, one of which comes from Max Weber. He supposes the bureaucracy as a machine that is prepared to carry out and realize the goals to be achieved. Therefore, every employee of the government bureaucracy is considered as a removable engine drive from personal interests.

According to Weber, as long as these conditions are met and the concept of bureaucracy as a machine is run according to established procedures, the accountability of bureaucratic officials can be realized, and organizational effectiveness can be achieved. This view makes the bureaucracy a neutral instrument from any interests as well as a professional organization (Firnas, 2016).

Weber's understanding of the bureaucracy was further criticized by experts who emerged after him. One of them was Nigro and Nigro (dalam Sharma \& Sadana, 1960) who argued that a public official was never separated from politics because they were engaged in politics. Graham Allison (in Frederickson, Smith, Larimer, \& Licari, 2018) explained that the emergence of politics in the bureaucracy is assumed to originate from the empirical facts of the role and behavior of politics in the bureaucracy, which in this view administration is not a solely technical and value-free activity and separated from politics. The view that politics and bureaucracy are a unity also stems from the understanding that every action taken by the government is the result of bargaining and compromise between various government organizations, or it can simply be understood that the bureaucracy also has political power. Peters \& Peters (2018) explained that there are four important powers held by the bureaucracy, namely personification of the state, mastery of information and expertise, decision making, political support, high social status and permanent and stable institutions. 
Based on these explanations, the unification of politics and bureaucracy is a necessity even though political involvement in the bureaucracy must also be limited, otherwise several unwanted events will occur such as:

- The emergence of political intervention in the placement of bureaucratic positions;

- Abuse of authority over financial resources and public facilities used by bureaucrats to support their political affiliations; and

- There has been a partiality of groups who are politically aligned with a bureaucrat

These events can be anticipated in several ways (Daniarsyah, 2015; Sudrajat, 2017), including:

- Making rules so that every member of the bureaucracy, in this case, bureaucrats are not involved in practical politics;

- The selection of public servants based on merit systems;

- Making rules that limit a public servant in expressing his/her opinion on policies issued by the government, meaning that a public servant can not necessarily and freely give comments on policies made by the government. If there is input to the policy, he/she can provide input directly, clearly and objectively to the government; and

- A public servant must implement every decision for every policy even if it is not in accordance with his/her political interests and opinion.

In the end, bureaucratic neutrality is not talking about how a bureaucrat can be free from various political values because of the true politics and bureaucracy is a unity, but it is about bureaucrats who can continue to prioritize nationalism, socialism, justice, and humanism above the interests their politics in carrying out their duties (Daniarsyah, 2015). Another opinion regarding neutrality is also expressed by Miftah Toha. According to him, bureaucratic neutrality is basically a system where bureaucracy will not change in providing services even though there has been a change of political leadership in a country.

\subsection{Bureaucracy Neutrality In Indonesia}

In accordance with the previous explanation related to the concept of neutrality in bureaucracy, neutrality is no longer interpreted as an apolitical condition of each bureaucratic member but how a bureaucratic member can continue to uphold the values of 
humanism, socialism, justice, and nationalism and remain loyal in performing their duties despite the occurrence change of political leadership in a country. One way that can be done to realize these conditions is by manifesting these values into a binding regulation. Changing these values into regulations will enable better coordination between individuals in the bureaucracy to realize them and can also be a guide for the members of the bureaucracy in carrying out their activities (Weichbrodt, 2010).

In Indonesia, neutrality of the State Civil Apparatus is directly related to the code of ethics of the State Civil Apparatus. The code of ethics itself can be interpreted as a set of rules made to regulate people's behaviors in an organization or in this study within the bureaucracy. Based on the study conducted by White (1999), in developing countries, the implementation of the code of ethics has a positive correlation with the effectiveness of public services. It means that the higher the level of implementation of the code of ethics by a public servant, the higher the effectiveness of his/her service will be.

Besides functioning to improve organizational effectiveness, the code of ethics also has several other functions, such as (Gilman, 2005): (1) The code of ethics will increase the likelihood of someone to behave in the right way. If associated with bureaucratic neutrality, the code of ethics will help each member of the bureaucracy to continue to maintain the values previously agreed; (2) A good code of ethics will help focus the member of the bureaucracy to take the right actions for the right reasons; (3) The code of ethics does not take over the morality of a public servant rather than providing a strong prima facie reason for a bureaucratic member or public servant to act and do something; and finally (4) The code of ethics can function as a professional statement expressing public service commitments to a set of moral standards.

The code of ethics of a bureaucrat or public servant in Indonesia has been regulated in various laws, ranging from Law Number 43 of 1999 concerning Civil Servants to the most recent being Law Number 5 of 2014 concerning State Civil Apparatus. There are several codes of ethics listed and must be implemented by a State Civil Apparatus based on Law Number 5 of 2014, including:

- Carrying out their duties honestly, responsibly, and with high integrity;

- Carrying out their duties with care and discipline;

- Serving with respect, courtesy and without pressure; 
- Carrying out their duties in accordance with statutory provisions;

- Carrying out their duties in accordance with orders from superiors or authorized officials as long as they do not conflict with the provisions of the legislation and ethics of the government;

- Maintaining confidentiality that concerns state policy;

- Using state wealth and assets in a responsible, effective and efficient manner;

- Ensuring that conflicts of interest do not occur in carrying out their duties;

- Providing information correctly and not misleading to other parties who need the information related to service interests;

- Not misusing state internal information, duties, status, power, and position to obtain or seek benefits for themselves or for others;

- Upholding SCA basic values and always maintaining SCA reputation and integrity; and

- Implementing the provisions of the legislation regarding the discipline of SCA.

The neutrality itself is indirectly manifested in the points avoiding conflicts of interest in carrying out their duties and upholding the basic values of SCA and always maintaining the reputation and integrity of SCA. This is because one of the basic values of SCA stated in the law is carrying out the task in a professional and impartial manner.

Although the issue of code of ethics and neutrality has been regulated in the Law, the tow aspects are often violated especially before the general election of the executive at the local and national level. The following will show examples of violations of SCA neutrality that have occurred in general elections in Indonesia from time to time.

\subsubsection{Election}

Rozi (2006) found several cases of violations of neutrality in the first Indonesian Election in the reform era including:

\section{A. South Sulawesi}

- Use of development programs and government budgets as a means of election campaigns;

- Use of office facilities political party purposes;

- Use of office facilities certain party campaigns;

- Bureaucratic officials secretly or openly supported certain parties; and 
- Head of Maiwa District, Enrekang regency gathered the village heads to support and win the Golkar party.

\section{B. North Sumatra}

- In Medan Johor District, a district official ordered his subordinates to simplify KTP matters for residents who voted for the Golkar Party;

- In Salina Kuta District, in Simalungun, Pematang Siantar, the district head invited all LKMD management to the district office to discuss the Golkar Party cadre refreshment event. At that time, several LKMD members did not want to come to the event that had been discussed earlier. Under pressure from the district head, the village head threatened anyone who was absent from administrative action or being fired from the LKMD.

\section{Central Sulawesi}

- The Molangato village government apparatus, Palu, distributed Rp.20,000-Rp.25,000 to the people who were in the interests of Golkar;

- Deputy Regent of Dati II of Luwuk Regency who was a civil servant became one of the political party members and served as the Chairman of the Branch Leadership Council of Partai Amanat Nasional;

- $\quad$ One of SMPN Palolo 1 teachers who was a civil servant announced to the community at the Arrahman Mosque, Ranteleda Village, Palolo District, Donggala Regency to join the Golkar Party campaign

\section{East Java}

- Civil servants bought voting support for certain parties. On May 18, 1999, Brother Asmaun, a civil servant in Sampang District, gave money for the Golkar party cadre meeting on May 11, 1999. He also provided basic food for the Social Safety Network (JPS) which was used as a tool through the village head so that the people who received it chose the Golkar Party;

- Civil servants who became administrators of political parties: Civil Servants who were administrators of political parties in the Sampang Rengency Madura, among others, 
were the officials of the Golkar Party, Drs. Herman Effendi, Drs. H. Ach. Ja'far, Drs. H. Marzuki Hasyim, Drs. H. M. Bachir. Meanwhile, the civil servant who was the organizer of the Partai Kebangkitan Bangsa is H. Hasan Abrori.

\subsubsection{Election}

This year was the second election in the reform era. Unlike the previous election, in this election, for the first time, direct presidential and vice-presidential elections were held. One case related to neutrality that can be found in this election is the case in Tabanan Bali. It was found that the Village Head and Civil Servants were mobilized by the Mega-Hasyim Campaign Team to provide support to the presidential and vice presidential candidates (Firnas, 2016).

\subsubsection{Election}

In the 2009 election, there were still many violations of neutrality committed by the State Civil Apparatus. Based on the recapitulation of the campaign report made by Election Oversight Body on March 25, 2009, violations of neutrality committed by SCA were found as follows:

Table 1.

Violations of neutrality committed by SCA

\begin{tabular}{|c|c|c|c|}
\hline No & Province & Wearing SCA Attributes & \\
\hline 1 & $\begin{array}{l}\text { Nangroe } \\
\text { Darussalam }\end{array}$ & & 2 cases \\
\hline 2 & Sumatera Barat & & 3 cases \\
\hline 3 & Jawa Timur & & 1 cases \\
\hline 4 & Bali & & 3 cases \\
\hline 5 & Nusa Tenggara Barat & & \\
\hline 6 & Kalimantan Barat & & 1 cases \\
\hline 7 & Kalimantan Selatan & 1 cases & \\
\hline 8 & Sulawesi Selatan & & 2 cases \\
\hline \multirow[t]{4}{*}{9} & Sulawesi Utara & & \\
\hline & & & 1 cases \\
\hline & & & 1 cases \\
\hline & & & 1 cases \\
\hline
\end{tabular}




\subsubsection{Election}

The 2014 election was the first election after the issuance of Law Number 5 of 2014

concerning State Civil Apparatus. Although the regulations had been updated, there were still cases of violations of neutrality committed by SCA, especially in legislative elections like two cases of civil servant involvement in campaigns in Sukoharjo and Wonosobo and four cases of use of state facilities for campaigns by civil servants in Cilacap, Demak and Surakarta. Some quite detailed cases can be seen in cases of violations committed by (1) Muslikhah as a civil servant in Purworejo Regency who also distributed goods in the form of reading glasses, biscuits, etc. and (2) Agus Hermawan as a civil servant involved in the campaign actively participating in distributing campaign material in the form of Democratic Party t-shirts.

\subsubsection{Election}

In the 2019 general election contestation, Badan Kepegawaian Negara (2019) revealed that there were approximately 990 violations of neutrality committed by the State Civil Apparatus. Most of these violations were committed in cyberspace or social media. In this election, there has been a shift in the pattern of SCA participation in practical politics. In the past, SCA openly conducted such activities in the real world, but now they are more engaged in political activities in the digital world through social media.

Based on these historical data, although there are regulations that have been established to maintain the neutrality of SCA from time to time, there are still many of them who commit violations, starting from violations that are committed directly using campaign attributes to the latest by doing various uploads that support one candidate on social media. Why did it happen? Demir (2017) identified two main factors that cause nonneutrality in the bureaucracy, namely the culture of Patronage and Partisans.

The first is patronage culture. Patronage relations in politics are a specific type of political external economies where the patron (someone who has political power) tends to protect his party members (clients). This relationship then results in a "clientistic policy" in which the existing economic resources will be distributed to political advocates and partisan groups from the government. This culture is also seen in the form of protection 
given by a politician to each of his supporters in the bureaucracy or everyone who is close to his party (Auyero, Lapegna, \& Poma, 2009; Pappas, 2009; Urban \& Willerton, 1993). Furthermore, partisan culture, in some cases of bureaucracy, is a tool of a political group and bureaucratic elites who want to increase their political power in government. To overcome this, in this cultural perspective, bureaucracy, which is a public servant, can also develop a group of interests or identities originating from internal bureaucracy that aims to transform to achieve organizational goals. If the group is inherently linked to a political party, the results will return to partisanship. However, this time the condition will be referred to as a "reverse partisanship." Nevertheless, both types of conditions are equally a threat to bureaucratic neutrality (Demir, 2017).

\subsection{Birocracy Neutrality In Digital Era}

Reflecting on the experience of the 2019 general election, it was found that currently there has been a change in the pattern of participation of an SCA to digital media through social media. Sudrajat (2017) stated that at the moment, freedom of speech on social media had given problems to the existence of the concept of bureaucratic neutrality. This phenomenon must be responded by every government by issuing policies that are in accordance with the political conditions in the country. There are several examples of world governments that have issued policies to maintain the concept of neutrality. The countries with good governance performance are, such as, Japan, China, Germany, France, and Denmark which have created a modern Weberian bureaucracy which operates under authoritarian conditions namely by limiting the rights of giving opinion of a bureaucrat. The motives for creating these conditions do not originate from the grassroots Movement but from political elites due to national security (Green \& Hart, 1996).

Furthermore, there are several reasons that these countries take into consideration when establishing this policy, namely:

- A bureaucrat must support the law, respect political supremacy, and uphold the value of accountability;

- Bureaucrats are responsible for serving the public and supporting the democratic process;

- Bureaucrats must be independent and committed to the values of professionalism and competence; and 
- $\quad$ Selected candidates must respect the contribution of professionalism and integrity of a bureaucrat in every administrative process.

\subsection{Birocracy Neutrality In Digital Era: Case Study Of 2019 Indonesian Elections}

The BKN report in 2019 found that approximately 990 SCAs violated neutrality by practicing practical politics dominated by the use of social media. This study seeks to illustrate these conditions by analyzing the communication patterns created on Twitter during the general election and identifying the involvement of SCA in these political activities.

\section{Methods}

The method used in this study refers to one type of method commonly referred to as mixed research or mixed methods. Mixed research is used in this study because it is a combination of two research methods namely qualitative and quantitative. Creswell (2010: 5) defines mixed research as a research approach that combines qualitative research and quantitative research. The mixed research method in this study is a sequence of quantitative and qualitative analyses with the aim of combining quantitative and qualitative data to obtain a more complete analysis. This is supported by the opinion of Abbas (2010: 222) which explains that the mixed research method has the goal of identifying the component concepts (sub concepts) through the quantitative data analysis and gathering qualitative data to expand the information available. In using this mixed research, the strategy used in this study is a sequential explanatory strategy. This strategy emphasizes the collection and analysis of quantitative data in the first stage followed by analysis with qualitative methods based on quantitative results that have been taken.

The data were processed using Netlytics software that functions to identify problems, especially taking data related to the tweets about politics that lead to hate speech or taking a side on one group. The quantitative data were then processed using qualitative methods through deeper observation. Observation activities are empirical scientific activities based on facts in the field and texts (Adler \& Adler, 1987: 78; Anderson \& Mayer, 1988: 32; Denzin \& Lincoln, 2009: 523). Observations were made in order to find out the accounts that may be of bureaucrats who violated the code of ethics by identifying a Twitter account using certain criteria to assess whether the owner of that account is a State Civil Apparatus. 


\section{Results and Discussion}

In this digital age, bureaucratic neutrality is a challenge that must be faced by every bureaucrat. Someone can upload anything at any time without thinking about whether it is good for sharing with the public. Plus, nowadays, someone is interested in following a trend. The development of trends makes social media consumption also increase. In connection with the 2019 general election phenomenon which has attracted a lot of public attention, the researcher used this phenomenon to collect the data through netlytics because social media is now also used as a place to carry out political activities such as to support or bring down one candidate for president and vice president. The data collection in this study was carried out in stages during the election of presidential and vice-presidential candidates.

The social media chosen as the locus of data collection in this study is Twitter because it can be used not only to interact but also to make predictions such as election results, capital market conditions, etc. (Bollen, Mao, \& Zeng, 2011). Because of this ability, a lot of studies have emerged using communication patterns formed on Twitter to describe and predict political matters such as during the presidential election.

The data were retrieved using the API (Application Programming Interface) provided by Twitter by entering several keywords. The keywords taken in this study are based on the hashtags that dominated Twitter at the time. Some keywords taken are as follows:

Table 2.

Number of Tweets of Netlytics Results

\begin{tabular}{lll}
\hline No & Hashtags & Quantity \\
\hline 1 & PrayForIndonesiaDemocracy & 591 Tweets \\
2 & SaveIndonesia & 2272 Tweets \\
3 & TangkapJokowi & 1055 Tweets \\
4 & TangkapPrabowo & 1639 Tweets \\
5 & MakhakamahKedaulatanRakyat & 1951 Tweets \\
\hline
\end{tabular}

From various kinds of tweets that emerged, the researcher then categorized neutral or non-neutral tweets. Neutral tweets contain tweets that do not support one of the candidates and only describe political conditions or express aspirations while non-neutral 
tweets contain supports to candidates who are advancing into political contestation, for example:

Table 3.

Neutral Tweet Grouping

\begin{tabular}{|c|c|c|}
\hline No & Hashtag & Example \\
\hline 1 & PrayForIndonesiaDemocracy & $\begin{array}{l}\text { All we Need is LOVE. No Gun, No War, No } \\
\text { Hoax, Nor } \quad \text { Provocation!!! } \\
\text { \#PrayForIndonesiaDemocracy } \\
\text { @prabowo https://t.co/HIXS8fAOaZ }\end{array}$ \\
\hline 2 & SaveIndonesia & $\begin{array}{l}\text { "My struggle is easier because it is against the } \\
\text { invaders, but your struggle will be more } \\
\text { difficult because it is against your own } \\
\text { people," Sukarno. \#saveindonesia } \\
\text { https://t.co/09KxNVSkcU }\end{array}$ \\
\hline 3 & MakhakamahKedaulatanRakyat & $\begin{array}{l}\text { When justice and democracy are torn apart, } \\
\text { people will fight. People are the owner of the } \\
\text { highest sovereignty in the Republic of } \\
\text { Indonesia. \#MahkamahKedaulatanRakyat } \\
\text { \#MahkamahKedaulatanRakyat } \\
\text { \#MahkamahKedaulatanRakyat }\end{array}$ \\
\hline
\end{tabular}

Table 4.

Unneutral Tweet Grouping

\begin{tabular}{|c|c|c|}
\hline No & Hashtag & Example \\
\hline 1 & PrayForIndonesiaDemocracy & $\begin{array}{l}01 \text { is also wrong. Why are you so } \\
\text { authoritarian? Every citizen who criticizes you, } \\
\text { he will be criminalized, even clerics. } 02 \text { is also } \\
\text { wrong. Why voicing people power? They can } \\
\text { take a legal way, can't they? } \\
\text { \#PrayForIndonesiaDemocracy } \\
\text { \#TangkapDalangNext \# actions22mei } \\
\text { \#TNIersamaKedaulatanRakyat }\end{array}$ \\
\hline 2 & SaveIndonesia & $\begin{array}{l}\text { @opposite_6890 What is the wrongdoing } \\
\text { regime? What do you mean by crossing the } \\
\text { line? There are only wrongful presidential } \\
\text { candidates. They have lost, but they don't } \\
\text { want to admit it. They use ISLAM for political } \\
\text { means. They have crossed the line that the } \\
\text { country must bother with the fools who want } \\
\text { to demonstrate for their sake. \#saveindonesia }\end{array}$ \\
\hline 3 & TangkapJokowi & $\begin{array}{l}\text { \#Tangkapjokowi \#TangkapJOKOWI } \\
\text { \#TangkapJOKOWI Because they can't value } \\
\text { people's lives. }\end{array}$ \\
\hline
\end{tabular}


Prabowo has been too far! He must not be let loose like 1998. \#TangkapPRABOWO !!

@Astuty64 Let's make the bad name of this regime to the international world. The leader of this country is the result of cheating. \#MahkamahKedaulatanRakyat \#MahkamahKedaulatanRakyat

After categorization, it was found that most of the tweets (5361 tweets) that appeared were not neutral or contained support for one of the candidate pairs. The phenomenon of political activity reinforces the findings of Stieglitz \& Brockmann (2012) which suggest that there has been a shift in political communication patterns in society from conventional to online communication patterns caused by the development of Web 2.0 technology where every Internet user, not only political party elites, can create his/her own content and form political discourse on social media.

Furthermore, to identify the presence of SCA in the support tweets of a candidate pair, the researcher observed various accounts that were considered not neutral in the data by tracing the account profile on Twitter. The observation was carried out by checking the profile photo, biodata, until the history of the uploaded tweet. From some of these indicators, the researcher tried to assess whether the account owner was an SCA or not. The observation becomes a series of research processes with qualitative methods. From various accounts that appear, the results observed are found an account that is indicated as owned by a bureaucrat. This is shown from the profile picture that wears the State Civil Apparatus uniform, as shown in the picture below.

Picture 1.

Profile picture of an alleged SCA

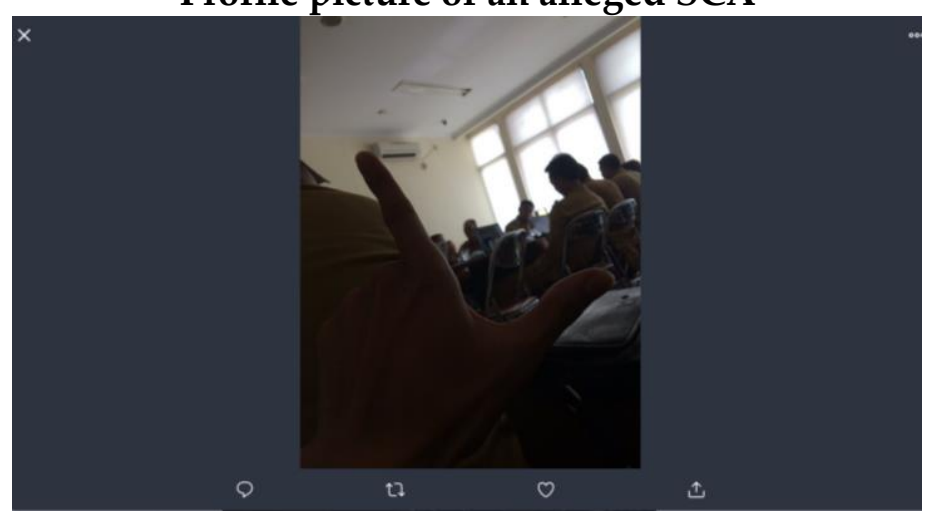


The account quotes words in support of one of the candidates for president and vice president. Below is one quote re-uploaded by the account owner.

\section{Picture 2.}

\section{Example of Quotes Re-quoted by the SCA Account}

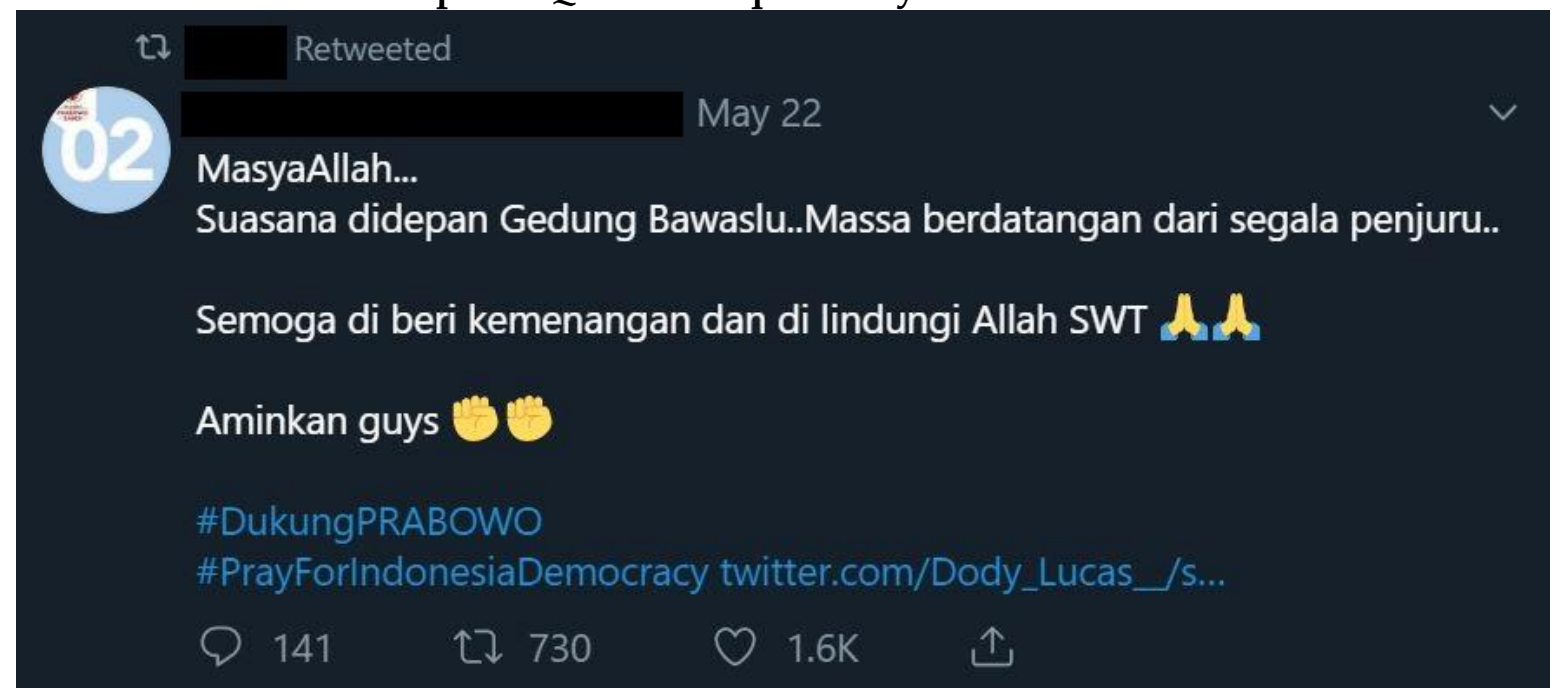

After being indicated as an SCA, further observations were made on the account. From the results of the observation, several tweets that supported one pair of candidates for president and vice president were found. This clearly violates the neutrality of SCA while at the same time reinforcing the opinion of Sudrajat (2017) stating that at this time, freedom of giving opinion on social media has given problems to the existence of the concept of bureaucratic neutrality. According to Prasojo (in Riris Katrina, 2010: 20), there are three forms of violation of the neutrality of SCA in elections. The first is abuse of authority, among others, issuing rules that oblige campaigns to subordinates, collecting funds for certain political parties, granting business licenses accompanied by certain demands for support, using government assistance for campaigns, changing official travel expenses, and forcing subordinates to finance campaigns from the state budget. The second is the use of state facilities directly; for examples the use of official vehicles, official houses, and government offices and their attributes. The third is providing other supports, such as donation assistance, covert campaigns, putting attributes in the office, using attributes, attending campaign activities using uniform and accessories, and omitting campaign violations using state facilities and unfair or discriminatory treatment of the use of state facilities.

The violations that the researcher found are related to the provision of other supports, such as donation assistance and covert campaigns. This certainly violates the code of ethics as an SCA. It is also part of shirking or partiality. Pierre, J., \& Peters, B. G. (2017) 
defines partiality shown by someone directly in political choices is considered to reduce his professionalism and existing ethical norms. This opinion means that with the existence of partiality or non-neutrality the State Civil Apparatus (SCA) will affect the goals set by the organization.

This phenomenon must be addressed immediately so that civil servants can be more committed to the policies of the government and make the policy as their goal in working instead of achieving personal goals. From this opinion, SCA must comply and obey the policies of the government. On the other hand, SCA which is a state asset must also support the active government. Another impact is also found in the opinion of Ting (2001) who studies about a work unit that is reluctant to work and may be negligent in policy making.

SCA neutrality in Indonesia has been regulated in Law Number 5 of 2014 or better known as the SCA Law. In Article 5 paragraph (2) letter E in SCA Law, SCA carry out their duties in accordance with orders from superiors or authorized officials insofar as they do not conflict with the provisions of the laws and regulations and government ethics. This means that SCA is allowed to refuse or not carry out orders from superiors which, according to him/her, violate the SCA code of ethics and code of conduct. It is also stated in Article 9 paragraph (2) of Law Number 5 of 2014 concerning State Civil Apparatus that SCA must be free from the influence and intervention of all groups and political parties. The neutrality arrangement of Civil Servants is intended to maintain their unity and cohesiveness so that they can devote more attention to their duties both as public servants and as state servants. In this regard, the neutrality of Civil Servants is more focused on the interests of the state than on the interests of the government. The political dichotomy has a role in creating SCA neutrality. Politics and administration are two different things. Therefore, it is necessary to have clear boundaries regarding the differences between the two. Thus, SCA is more oriented towards building political closeness with the authorities rather than building competence and performance to guarantee their career (Prasodjo \& Rudita, 2014). The politics in every power makes the closeness between individuals based on the interests of certain groups. Perry (1996) outlines four basic dimensions of public sector motivation; they are 'Interest in policy making and politics', 'public interest', 'empathy' and 'self-sacrifice'.

Speaking about the neutrality of SCA is certainly related to the code of ethics inherent in them. This is supported by the opinions of Sahya Anggara (2016: 405) that in general the 
formulation of a minimum code of ethics is based on four aspects of consideration as follows:

1 Special skill professionalism possessed by someone from formal education, talent, as well as the competence to do something;

2 Accountability of a person's readiness to take responsibility for whatever he does related to his profession and role so that he can be trusted;

3 Maintaining confidentiality of an ability to maintain trust by being careful in providing information. A professional must be able to select things that can be shared with the public and information that needs to be kept as confidentiality. This is done in order to maintain the reputation of a company and the profession he/she holds.

4 Independence

5 Neutrality or impartiality of one party. Being aware of the limitations in expressing something is also one of the considerations of the code of ethics.

On the other hand, there is a critical perspective that positions the bureaucracy as an instrument of power. This perspective considers that there is no bureaucracy that is entirely neutral. The Marxist approach sees bureaucracy as an instrument of the interests of the ruling class to dominate, discipline, and exploit the non-ruling class (Marx, 1967; Lenin, 1871). Even, Max Weber as the originator of the concepts of "ideal bureaucracy" and "bureaucratic rationality" acknowledges the bureaucratic neutrality (see Max Weber, 1947; 1968). This is according to Seajeng Kadarsih, Tedi Sudrajat. et al. (2014) that the source of the problem of enforcing neutrality of civil servants lies in the weak function of coordination and application of sanctions. This is based on the biased and substantive issue in placing the neutrality of SCA as a legal object. As a result, there appears a sectoral policy that cannot resolve the problem, both from the institutional, management, and law enforcement elements. The authority of the regional head as the supervisor of staffing and determining staffing policies is a factor in the slow enforcement of neutrality. This is supported by the opinion of Riris Katharina (2012) that regional heads have a very big role in the development of regional civil servants. The role is used to intervene the bureaucracy which in turn bureaucrats become not neutral and professional. It is recommended that the role of the regional head as the supervisor of regional civil servants be evaluated and given to the regional head secretary as the highest career official in the region. 
Neutrality becomes important where the neutrality/impartiality attitudes of the SCA create stability in the implementation of democracy fairly and without any conflict between supporters. Creating supportive conditions also needs to be done to encourage the neutrality of SCA. The uploaded tweets become positive if the content is positive and does not distribute hoaxes. It is feared that the existence of negative tweets or hoaxes worsens the situation. The neutral attitude that must be possessed by SCA becomes a preventive measure in facing information distribution that is easier and wider

\section{Conclusion}

Neutrality of the State Civil Apparatus (SCA) was a part of code of ethics of the State Civil Apparatus. The code of ethics of a bureaucrat or public servant in Indonesia has been regulated in various laws, ranging from Law Number 43 of 1999 concerning Civil Servants to the most recent being Law Number 5 of 2014 concerning State Civil Apparatus. In digital era, it was found that currently there has been a change in the pattern of participation of an SCA to digital media through social media. Freedom of speech on social media had given problems to the existence of the concept of bureaucratic neutrality. From the data we collected, it was found a SCA were not neutral or contained support for one of the candidate pairs.

\section{Acknowledgement}

This paper acknowledge MRG Scheme of PNBP-UNS Research Grant.

\section{References}

Abbas Tashakkori \& Charles Teddlie. (2010). Mixed Methodologi (Mengkombinasikan Pendekatan Kualitas dan Kuantitas). Yogyakarta: Pustaka Pelajar.

Adler, P. A., \& Adler, P. (1987). Qualitative research methods series, Vol. 6. Membership roles in field research. Thousand Oaks, CA, US: Sage Publications, Inc.

Anggara, Sahya. 2016. Ilmu Administrasi Negara. Bandung: CV Pustaka Setia

Auyero, J., Lapegna, P., \& Poma, F. P. (2009). Patronage politics and contentious collective action: A recursive relationship. Latin American Politics and Society. https://doi.org/10.1111/j.1548-2456.2009.00054.x 
Badan Kepegawaian Negara. (2019). Strategi Penegakan Netralitas Asn Dalam Birokrasi Pemerintahan.

Creswell, J. W. (2010). Research design: pendekatan kualitatif, kuantitatif, dan mixed. Yogjakarta: PT Pustaka Pelajar.

Daniarsyah, D. (2015). Bureaucratic Political And Neutrality Of Bureaucracy In Indonesia. Jurnal Ilmu Politik Dan Komunikasi, V(2), 85-94.

Demir, F. (2017). Depolitization of Bureaucracy: The Case of Central and Eastern European Countries. International Journal of Public Administration, 40(1), 54-64. https://doi.org/10.1080/01900692.2015.1072556

Denzin \& Lincoln. 2009. Handbook of Qualitative Research. Yogyakarta : Pustaka Pelajar

Firnas, M. A. (2016). Politik Dan Birokrasi: Masalah Netralitas Birokrasi Di Indonesia Era Reformasi. Jurnal Review Politik, 6(1), 160-194. Retrieved from http://jurnalpolitik.uinsby.ac.id/index.php/jrp/article/view/80

Frederickson, H. G., Smith, K. B., Larimer, C. W., \& Licari, M. J. (2018). The public administration theory primer, third edition. In The Public Administration Theory Primer, Third Edition. https://doi.org/10.4324/9780429494369

Gilman, S. C. (2005). ETHICS CODES AND CODES OF CONDUCT AS TOOLS FOR PROMOTING AN ETHICAL AND PROFESSIONAL PUBLIC SERVICE : Comparative Successes And Lessons. In PREM, the World Bank.

Green, L., \& Hart, H. L. A. (1996). The Concept of Law RevisitedThe Concept of Law. Michigan Law Review. https://doi.org/10.2307/1289966

Pappas, T. S. (2009). Patrons against partisans: The politics of patronage in mass ideological parties. Party Politics. https://doi.org/10.1177/1354068809102247

Perry, JL, 1996, Measuring public service motivation: An assessment of construct reliability and validity, Journal of Public Administration Research and Theory 6, 5-23

Peters, B. G., \& Peters, B. G. (2018). The Politics of Bureaucracy. In The Politics of Bureaucracy. https://doi.org/10.4324/9781315813653-5

Pierre, J., \& Peters, B. G. (2017). The shirking bureaucrat: a theory in search of evidence? Policy $\mathcal{E}$ Politics, 45(2), 157-172. 
Prasodjo, Eko \& Laode Rudita. 2014. Civil State Apparatuslaw : Building The Professionalism Of Civil State Apparatus. Jurnal Kebijakan dan Manajemen PNS vol. 8, 13-29. Badan Kepegawaian Negara

Rozi, S. (2006). Zaman Bergerak, Birokrasi Dirombak: Potret Birokrasi dan Politik di Indonesia. Yogyakarta: Pustaka Pelajar.

Sharma, \& Sadana. (1960). Public Administration in Theory and Practice. New Delhi: Kitabmahal.

Sudrajat, T. (2017). Questioning The Essence Of Bureaucratic Neutrality. 43(Icas), 211-214.

Tamma, S. (2018). Paradox of Bureaucracy Neutrality in The Indonesia Regional Election. Palita: Journal of Social-Religion Research, 1(2), 95-112. https://doi.org/10.24256/pal.v1i2.69 Thoha, M. (2014). Birokrasi Politik dan Pemilihan Umum di Indo- nesia. Jakarta: Prenadamedia Group.

Ting, M. M. (2001). Public Choice, 106(3/4), 243-274.

Urban, M. E., \& Willerton, J. P. (1993). Patronage and Politics in the USSR. Russian Review. https://doi.org/10.2307/130680

Weber, M. (1978). Economy and Society. An Outline of Interpretative Sociology. Economy and Society. An Outline of Interpretative Sociology. Berkeley:

Weichbrodt, J. (2010). Rules and Routines in Organizations. Fourth International Conference on Organizational Routines, (February). Retrieved from http://ecitations.ethbib.ethz.ch/view/pub:69338

White, R. D. (1999). Public ethics, moral development, and the enduring legacy of Lawrence Kohlberg: Implications for public officials. Public Integrity, 1(2), 121-134.

Wilson, W. (1941). The Study of Administration. Political Science Quarterly. https://doi.org/10.2307/2143644 